\title{
Competitiveness Analysis of Indonesian Pepper in International Market
}

\author{
Christine Amorita ${ }^{1}$, Arief Daryanto ${ }^{2}$, Sahara $^{3}$ \\ ${ }^{1}$ School of Business, IPB University, Bogor, Indonesia \\ ${ }^{2}$ Vocational School, IPB University, Bogor, Indonesia \\ ${ }^{3}$ Faculty of Economics and Management, IPB University, Bogor, Indonesia
}

Corresponding Author: Christine Amorita

\begin{abstract}
Indonesia is one of the world's largest pepper producing countries and most of Indonesia's pepper production is exported abroad. Apart from the superiority of Indonesia's natural resources, namely as a country with the secondlargest area of pepper cultivation, now competition between countries cannot be measured only bythe number of exports it owns. The existence of synergy between countries in producing a product with high economic value is evidence of trade integration between countries. This study aims to analyze the comparative advantage of Indonesian pepper compared to Vietnam, Brazil, India, and Malaysia, to analyze the competitive advantage of Indonesian pepper, and to analyze the value chain of Indonesian pepper. This study used a sample of five countries, namely Indonesia, Vietnam, Brazil, India, and Malaysia. This research used quantitative and qualitative research approaches. The methods used in this research used Revealed Comparative Advantage (RCA), Porter's Diamond Theory, and value added analysis. The analysis results show that the five competing countries have a comparative advantage over pepper; Indonesia has a competitive advantage in conditions of natural resource factors. Indonesia's participation in the global value chain is declining. The main focus of the government in 2020 is on the input, production, capital, and market sides.
\end{abstract}

Keywords: comparative advantage, competitive advantage, pepper, value added, value chain

\section{INTRODUCTION}

One of the superior and economically valuable plantation commodities to support Indonesia's economic growth in the international market, especially the spice market, is pepper. Pepper (Piper nigrum L.) is a potential spice plant and has economic value in international trade. Indonesia is one of the world's largest pepper producing countries and most of Indonesia's pepper production is exported abroad. According to International Pepper Community (2019), in the international market, Indonesia is included in the top 5 (five) largest pepper producing and exporting countries and competes with Vietnam, India, Brazil, and Malaysia for the last 10 years. The high ability of Indonesia to produce and export pepper is supported by the planted area of Indonesian pepper. The area of pepper planted in 5 countries can be seen in Table 1 below.

Table 1: Pepper Plantation Areal of Five Countries 2009 2018

\begin{tabular}{|c|c|c|c|c|c|}
\hline \multicolumn{7}{|c|}{ Pepper Plantation Areal (Ha) } \\
\hline Year & India & Indonesia & Vietnam & Malaysia & Brazil \\
\hline 2009 & 181.300 & 113.683 & 50.000 & 13.608 & 27.415 \\
\hline 2010 & 182.000 & 110.621 & 51.000 & 15.000 & 23.263 \\
\hline 2011 & 189.100 & 110.900 & 52.500 & 15.000 & 21.089 \\
\hline 2012 & 196.200 & 112.856 & 54.500 & 14.791 & 19.427 \\
\hline 2013 & 197.000 & 113.000 & 61.500 & 15.000 & 18.472 \\
\hline 2014 & 198.000 & 115.000 & 85.500 & 16.000 & 20.000 \\
\hline 2015 & 198.500 & 116.000 & 97.500 & 16.300 & 22.110 \\
\hline 2016 & 131.790 & 117.000 & 105.000 & 16.700 & 25.660 \\
\hline 2017 & 134.280 & 117.500 & 110.000 & 17.000 & 27.730 \\
\hline 2018 & 138.556 & 117.900 & 100.011 & 17.437 & 30.503 \\
\hline
\end{tabular}

In 2015 , the planted area for pepper in Indonesia reached 116,000 hectares with a total production of 49,000 tons. With this 
area, Indonesia is able to rank as the second largest planted area compared to the other four competing countries. The area planted in these five countries has increased overall from year to year and has been followed by varying rates of growth. On the other hand, apart from the advantages related to natural resources owned by Indonesia, seen from the second position of the largest pepper planting area among other competing countries, now competition between countries cannot be measured only by the number of exports it owns. According to the Trade Map (2019), the volume and value of Indonesian pepper exports in 2018 were dominated by pepper that was still intact or had not changed shape. The export value for this type of product is very significant compared to that of pepper that has been crushed or ground so that it turns into a powder. The volume and export value of each type of Indonesian pepper can be seen in Table 2 below:

Table 2: Indonesian pepper export value and volume
\begin{tabular}{|c|c|c|c|c|}
\hline HS code & Export Value (USD 000) & Export Volume (Ton) & Ranking & World share export (\%) \\
\hline 090411 & 147.389 & 46.503 & 3 & 10,3 \\
\hline 090412 & 5.073 & 1.111 & 14 & 1,3 \\
\hline
\end{tabular}

The synergy between countries in producing a product with high economic value is evidence of trade integration between countries. This phenomenon is known as the Global Value Chain (GVC). This condition became popular around the 1980s when the export value was no longer able to represent the real benefits of a country's economic size. The development of the global value chain has led to an increase in the series of activities in the production process of good or services. According to Nasir (2018), the performance of Indonesian pepper plantations has not been optimal, causing the export of the spice commodity to record a negative trend. International pepper price trends since 2015 have also decreased and have affected pepper prices in Indonesia. The fluctuating planting area also affects the production and export volume of pepper to the international market. All of these problems will have an impact on the ability of Indonesian pepper to face the intense competition in the international market because Indonesia's ability to meet demand is unstable. Based on the description above, regarding the contribution and intense competition between pepper exporting countries in the international market, there is a big opportunity for Indonesia to strengthen its role in the global market, especially if it can overcome specific challenges that hinder success along the pepper value chain.
Therefore, the study analyzed the comparative advantage of Indonesian pepper compared to Vietnam, Brazil, India, and Malaysia, to analyze the competitive advantage of Indonesian pepper, and to analyze the value chain of Indonesian pepper.

\section{LITERATURE REVIEW Value Chain}

Competitive advantage comes from the many activities that companies carry out to produce their products. A systematic way of examining how each activity interacts is known as a value chain. According to Kaplinsky and Morris (2001), the value chain describes a series of activities to produce goods or services which include various phases ranging from a combination of physical changes and various kinds of inputs from producers to consumers, as well as the delivery process to consumers. Value activities are divided into two types namely primary activities and support activities. The primary activity is a series of activities in the physical creation of a product and its sales, as well as transfers to buyers and also after sales assistance. There are five generic categories in primary activities, namely inward logistics, operations, external logistics, marketing and sales, as well as service. Meanwhile, there are four generic categories in support activities, namely purchasing, technology development, 
human resource management, and company infrastructure.

\section{Competitiveness Theory}

According to Tatakomara (2004), the concept of competitiveness is related to the ability of a commodity to enter foreign markets and the ability to survive in that market, meaning that if a product has competitiveness; it is the product that is in great demand by many consumers. Competitiveness is divided into two sides, namely comparative advantage and competitive advantage.

\section{Comparative Advantage}

Cho and Moon (2000) stated that in 1776 an economist, David Ricardo, revealed a theory known as the Ricardian Theory. He said that a country will still get benefit from trade even though it does not have an absolute advantage. Basically, the theory can explain how much exchange rates and profits are received from trading activities between countries, which was not previously stated by Adam Smith. This theory explains that the value of a good depends on the amount of labor devoted to producing that good and that comparative advantage arises from differences in the labor productivity of the country. Ricardo argues that imports can also benefit a country even though the country can produce these goods at a lower cost. This is the principle of comparative advantage, which underlies the advantages of division of labor, both among individuals, between regions, as well as between countries.

\section{Competitive Advantage}

This is based on the understanding that the prosperity of a country does not grow from the natural contribution of a country alone, but also depends on the capacity of its industry to innovate and carry out continuous renewal. Therefore, according to Porter (1990), the competitive advantage of an industry depends on the interaction between the following four attributes, namely:
1. Condition factor (factor condition). It divides into two types, namely basic factors and advanced factors. Basic factors include natural resources, climate, location, unskilled and semiskilled labor, and debt capital.

2. Demand conditions. The demand condition is related to the growth rate of a country's demand. The rapid growth of domestic demand will pressure companies in a country to make faster innovations by using large and efficient facilities, as well as reduce corporate concerns that the investments made will be futile and useless.

3. Related and supporting industries. Related and supporting industries are industries in which companies coordinate or various activities in the value chain and industries that involve products that complement companies from a certain country.

4. Firm strategy, structure, and rivalry. This is seen as the ability to create, organize, and manage companies. The existence of competitors is a strong stimulus to create a competitive advantage. Besides, there are two other variables can affect the diamond of nations competitive advantage, namely opportunity and government. The government is influential as a regulator of policies. The government is considered successful if it can play a role in supporting the four attributes directly related above, and companies can gain a competitive advantage without directly involving the government. The next supporting attribute is opportunity. According to Suandy (2003) opportunity is likened to a new invention or innovation that is beyond the reach of the company and has not been reached by competitors.

\section{METHODS}

The types of data used in this study are primary and secondary data. Primary data were obtained from pepper farmers, private exporters, brokers, and the 
International Pepper Community (IPC). Meanwhile, secondary data was obtained from various sources including the International Pepper Community (IPC), the Central Bureau of Statistics (BPS), the Directorate General of Plantations (DITJENBUN), the Ministry of Trade, the United Nation Comtrade (UN Comtrade), and the Trade Map.

\section{RCA Index}

Analysis of the comparative advantage of pepper using the Revealed Comparative Advantage (RCA) Index. The RCA index will show the comparison between the share of a country's commodity exports against the same share of commodity exports from around the world. Mathematically, the RCA index is as follows:

RCA Index: $\frac{\boldsymbol{X} \boldsymbol{i} \boldsymbol{j} / \boldsymbol{X} \boldsymbol{i t}}{\boldsymbol{X} \boldsymbol{w} \boldsymbol{j} / \boldsymbol{X} \boldsymbol{w i}}$

which is :

Xij : the export value of commodity $j$ from country $i$

Xit $\quad$ : total export value (product $\mathrm{j}$ and others) of country $i$

Xwj : the export value of commodity $\mathrm{j}$ in the world

Xwi : world total export value

If the RCA index value is $>1$, it means that the exporting country has a comparative advantage over the world average for that commodity. If the RCA value is $<1$, then the country does not have a comparative advantage in the product.

\section{Porter's Diamond Theory}

The competitive advantages of pepper obtained from Porter's Diamond analysis are factor conditions, demand conditions, related and supporting industries, company strategy, structure, and competition. In addition, analyzing 2 (two) supporting attributes of the competitive advantage of pepper, namely government and opportunities.

\section{Indonesian Pepper Value Chain Analysis}

The Indonesian pepper value chain will be analyzed using the Value Chain Approach. The Value Chain Approach is used to see the value additions given by each party to produce various preparations of pepper that are ready for export. This value chain will be divided into primary activities and support activities. Primary activities are the main activities that add value to the final product and support activities are supporting activities that add value to the pepper product indirectly. From the results of this analysis, information will be obtained about various obstacles and linkages between parties in the process of creating added value for export pepper so that it can describe the relationship between each party in the effort to create added value in pepper.

\section{RESULT AND DISCUSSION Comparative Advantages of Indonesian Pepper compared to Vietnam, Brazil, India, and Malaysia}

Comparative advantage or what is commonly referred to as natural advantage is basically based on the productivity of labor and the ability to produce good at a lower cost compared to others. Labor productivity to produce a good can be seen from the output produced per labor. In 2014 the labor productivity in the agricultural sector was 23.3 million per person and in 2018 it increased to 28 million per person. This increase in productivity indicates that the labor used in the agricultural sector is increasingly productive.

This increased productivity is the result of synergy between the Ministry of Agriculture and various parties in making efforts to modernize agriculture by developing agricultural technology, ranging from seeds, planting methods, calculating IT-based cropping patterns, to mechanization. Mechanization can save the use of labor and increase the added value of production, causing labor productivity in the agricultural sector to increase. Also, labor productivity is influenced by several factors 
including quantity, level of education, expertise, and age of the workforce (Sinungan, 1992).

With high labor productivity, it is expected that production will be more efficient and can produce products at relatively cheaper prices. However, Indonesia can no longer rely solely on the factor of increasing labor productivity but must also improve the management of other advantages such as land and natural resources which are still abundant. In addition, production costs are not only influenced by labor productivity but also other input cost factors. The amount of the allocation of pepper farming costs starting from the pre-production activities requires a farming cost of Rp. 25,000,000 or about 35.5 percent of the total cost until the planting is rehabilitated / rejuvenated. The value of the farming costs is due to the cost of procuring wood for death and labor costs. Meanwhile, the cost of farming in the production phase (for seven years) ranges from 4.4 million to 7.8 million rupiahs (Syam, 2004).

Such as the empirical test proposed by MacDougall in 1951 and 1952 and supported by Ballasa in 1950 and Stern from 1950 to 1959 by using labor productivity data and the number of exports for 25 industries in the United States and Britain which showed a positive relationship between labor productivity and the number of exports. Then this relationship can be analyzed using Revealed Comparative Advantage (RCA). RCA is the result of a comparison of the export value of a country's pepper against the export value of this commodity in the world in foreign currencies (US\$).

The results of the RCA analysis for Indonesian pepper obtained from 2008 to 2017 will be compared with the RCA values of the other 5 (five) producing countries also largest exporters of pepper, namely Brazil, India, Vietnam, and Malaysia. The following is a table of Revealed Comparative Advantage of the five producing countries and the world's largest exporter of pepper:

The RCA value of the five competing countries is $>1$ (one) and this means that each country has a comparative advantage over pepper. However, this value continues to decline until 2017 so that the results of the RCA analysis of the five competing countries cannot be a complete picture of the ability of Indonesian pepper to compete in the international market because there are still other factors that affect the competitiveness of pepper. In addition, according to Soetriono (2006), competitiveness is also the ability or ability of agricultural commodities to maintain profits and market share, so that producers have the ability to produce agricultural commodities so that they can maintain their business continuity.

Table 3: RCA Index of Five Countries 2008 - 2017

\begin{tabular}{|c|c|c|c|c|c|}
\hline \multirow{2}{*}{ Year } & \multicolumn{5}{|c|}{ Revealed Comparative Advantage (RCA) Index } \\
\cline { 2 - 6 } & Indonesia & India & Brazil & Vietnam & Malaysia \\
\hline 2008 & 17.76 & 8.18 & 7.17 & 65.10 & 3.43 \\
\hline 2009 & 14.57 & 4.65 & 7.25 & 73.78 & 3.42 \\
\hline 2010 & 17.91 & 4.10 & 6.16 & 67.04 & 3.59 \\
\hline 2011 & 9.71 & 5.53 & 7.12 & 69.53 & 3.79 \\
\hline 2012 & 17.08 & 3.83 & 6.07 & 53.12 & 2.68 \\
\hline 2013 & 14.13 & 4.10 & 9.23 & 50.09 & 2.84 \\
\hline 2014 & 11.04 & 3.46 & 7.87 & 39.59 & 3.19 \\
\hline 2015 & 16.15 & 5.06 & 8.06 & 27.81 & 2.94 \\
\hline 2016 & 14.44 & 3.51 & 6.47 & 26.86 & 3.05 \\
\hline 2017 & 9.39 & 3.08 & 8.46 & 34.88 & 2.23 \\
\hline Mean & $\mathbf{1 4 . 2 2}$ & $\mathbf{4 . 5 5}$ & $\mathbf{7 . 3 9}$ & $\mathbf{5 0 . 7 8}$ & $\mathbf{3 . 1 2}$ \\
\hline
\end{tabular}

\section{Competitive Advantage of Indonesian Pepper}

Globalization causes increasingly fierce business competition and has shifted the business paradigm from Comparative Advantage to Competitive Advantage, which forces businesses or companies and even countries to choose the right strategy. According to Anindita (2008), the competitive advantage which refers to Porter's Diamond Theory includes several attributes, namely factor conditions, demand conditions, supporting and related industries, strategies, structures, and competition between industries. 


\section{Factor Condition \\ a. Natural Resources}

Based on concession status, pepper plantations in Indonesia are divided into smallholder plantations (PR) and large private plantations (PBS). There are no large state companies that cultivate pepper in Indonesia. The domination of large smallholder plantations has greatly influenced the fluctuations in the area of pepper cultivation in Indonesia. Following is the production of pepper in 7 (five) pepper production centers in Indonesia as shown in the following table below:

Table 4: Total pepper production in 7 production center in Indonesia

\begin{tabular}{|c|c|c|c|}
\hline \multirow{2}{*}{ No } & Province & \multicolumn{2}{|c|}{ Production (Tonne) } \\
\cline { 3 - 4 } & & $\mathbf{2 0 1 7}$ & $\mathbf{2 0 1 8}$ \\
\hline 1 & Bangka Belitung & 34278 & 32811 \\
\hline 2 & Lampung & 13771 & 14450 \\
\hline 3 & South Sumatera & 7580 & 8108 \\
\hline 4 & South Sulawesi & 6790 & 6631 \\
\hline 5 & East Borneo & 6056 & 6484 \\
\hline 6 & West Borneo & 5499 & 5446 \\
\hline 7 & Southeast Sulawesi & 5050 & 5135 \\
\hline
\end{tabular}

Based on the explanation above regarding the condition of Indonesia's natural resources that support the development of pepper, it can be concluded that the area of pepper cultivation in Indonesia has the potential to be developed because it is still dominated by smallholder plantations, which mainly still use traditional cultivation techniques for pepper cultivation. Besides, an increase in acreage must also be accompanied by an increase in productivity so that pepper production and export volume can increases stable and can remain competitive in the international market.

\section{b. Human resources}

According to Yulihendri (2018), as one of the largest pepper production centers, the number of farmers who cultivate pepper is in Bangka Belitung until 2018 which is as much as 10,077. This number has decreased significantly since 2013, which initially amounted to 54,099 farmers. The number of farmers who cultivate pepper in Bangka Belitung and old age (>52 years) is relatively few or equivalent to $18.88 \%$
(Tiurlina, 2016). According to the Central Bureau of Statistics, the productive age for work is in the range of 15-64 years, which means that physically the pepper farmers in Bangka Belitung are still able to carry out farming activities.

However, pepper farming, which is dominated by smallholder plantations, has not been supported by the quality of farmers as the main actors. According to Tiurlina (2016), the skills possessed by pepper farmers themselves are still low, and this is due to several things, including a) innovation does not reach farmers, b) innovation does not suit farmers' needs, c) innovation is not yet understood and it is believed by farmers, d) difficulties in obtaining recommended production facilities, and e) limited farmers' capital. If this is allowed to continue, it will have an impact on the quantity and quality of Indonesian pepper yields in the coming year. Apart from farmers, other human resources that play a role in creating a competitive advantage in terms of trading channels are pepper traders and exporters. As in research conducted by Djulin (2002), the black pepper trading channel in Lampung Province was initiated by farmers who sold $80 \%$ of the black pepper produced to village traders and the rest was directly sold to collectors based in the district. As for the white pepper trading channel in Bangka Belitung started from farmers who sold white pepper to village traders or collectors which would then be sold to exporters based in Pangkal Pinang (the capital of the Bangka-Belitung Islands Province).

\section{c. Capital resources}

According to Yazmi (2017) in a financial analysis of white pepper farming in West Borneo, there are two types of capital costs needed, namely investment and operational costs. The investment costs include the cost of purchasing land, equipment for small agricultural equipment, the procurement of pepper seeds, purchasing stakes, land clearing, the costs of planting 
pepper and embroidery. Furthermore, operational costs in pepper farming are costs that are routinely incurred in running pepper farming including fertilizer, drug, material costs, labor costs and tax. The capital needed in pepper farming is quite large, but the guarantee for the income obtained due to uncertain price fluctuations has made farmers reluctant to plant pepper. In addition, supporting institutions such as farmer groups have not been widely felt, either as a training or extension forum or in order to strengthen the bargaining position of pepper farmers in marketing.

Based on the explanation above regarding the capital resources that support the development of pepper, it can be concluded that the institutional support for pepper farming is still not widely felt by farmers, especially the role in strengthening the bargaining position of farmers. However, there have been several efforts taken to help pepper farmers' capital, namely the Integrated Partnership Project (PKT) and Warehouse Receipt System (SRG) which are continuously being developed and are expected to be able to relieve farmers in terms of capital.

\section{d. Technology}

In order to increase the competitiveness of Indonesian pepper, it is absolutely necessary to support technological innovation, so that Indonesian pepper farming can have high productivity, which is accompanied by efficiency measures in production and marketing costs, quality improvement and consistency of quality standards (Rivaie, 2014). Most of the technology that has been disseminated to the community has been applied by farmers in their farming activities such as the use of superior seeds, but supervision from the government regarding the use of existing innovations is still lacking, resulting in innovations given to the community sometimes not being applied according to recommendations continuously.

\section{Demand condition}

The attribute of demand conditions to support the competitive advantage of Indonesian pepper can be seen from the large domestic consumption of pepper. Domestic consumption of pepper has increased from 2009 to 2018 . The average rate of increasing consumption of Indonesian pepper from 2009 to 2018 reached $6.4 \%$. When viewed from the total consumption and export of pepper to the international market, pepper production from 2009 to 2018 was still able to meet domestic and export needs. However, Indonesia continues to import pepper from countries such as Vietnam, India and the United States. In general, imports made by Indonesia are in the form of processed pepper such as pepper powder. Pepper powder is generally used as an additive in seasoning fast food products. This is indicated by the slow nature of the pepper processing industry in Indonesia so that it has not been able to meet the needs of domestic consumers. From the description of Indonesia's level of consumption of pepper above, it can be concluded that the demand conditions are not competitive yet.

\section{Supporting and related industries}

Related and supporting industries in this case, include upstream and downstream industries which are related to increasing the added value of pepper. The related industry is seen from the supplier of pepper seeds, in this case the research and development center for superior seeds, while the supporting industry is seen from companies that use pepper as the main raw material or additional raw materials for a product.

From the upstream side, parties related to the development of pepper are included in the research and development activities of pepper plants by the Research Institute for Medicinal Plants and Spices (BALITTRO) located in Bogor, West Java. In 2018 BALITTRO handed over 6,000 polybags of Natar 1 pepper seeds to the Agriculture and Plantation Service of the Province of Nangroe Aceh Darussalam as a 
follow-up to the Ministry of Agriculture's program to Restore Indonesian Spice. This pepper seed is a certified seed with the main seed class so that it meets the requirements as seed for the mother garden seed source which can be recommended for stipulation by the Director General of Plantation. In addition, in an effort to provide superior pepper planting material, the government through the Ministry of Agriculture in collaboration with BPTP has released several varieties of pepper, namely Petaling 1, Petaling 2, Lampung Daun Kecil, Chunuk, Natar 1, Natar 2 and Bengkayang.

The number of downstream industries that process pepper into processed products such as powder and pepper oil is still very minimal. According to the International Pepper Community, there are 57 business actors who provide seeds to processed pepper such as pepper powder, oil and oleoresin. Even though pepper production tends to increase every year. Therefore, it is feared that this situation could cause an oversupply because the ability to process pepper is still low.

\section{Firm strategy, structure, and rivalry}

In some pepper production centers, the market structure is generally oligopoly, in which there are several sellers and many buyers. However, the domestic pepper industry as described in the previous subchapter regarding related and supporting industries shows that companies in the domestic pepper processing industry are minimal while on the other hand an increase in population will also cause demand for pepper to increase. To meet this demand, producers and companies in the pepper industry are increasingly competing to grab market share, and this is highly dependent on the availability of supply in farmers and efforts to improve the quality and quality of the products produced so that they remain in demand by the market. Judging from the current market conditions for pepper, the five competitive forces as stated by Porter will be explained as follows:

\section{A. Threat of entry of newcomers}

The threat of entry of newcomers to an industry depends on how big the barriers to entry are and on the reaction of old competitors. One of the pepper processing companies in Indonesia with modern technology and international standards is PT Motasa Indonesia. Judging from the profile of PT Motasa Indonesia above, this company is one of the companies that have high development prospects in Indonesia and should be considered before the entry of a new pepper processing company. Generally, companies in an industry are interdependent, therefore the actions taken are generally competitive ones. This occurs because companies are trying to seize market share (Kholid, 2010). Easy or difficult barriers to enter an industry can also be seen through several indicators, namely product differentiation, capital requirements, and access to distribution (Kuncoro 2006).

PT. Motasa Indonesia obtains raw materials with a long life cycle and different seasonal variations from each supplier. From May to July is the peak of the harvest in Bangka Belitung, July-October Kalimantan, and September-April in Sulawesi. According to Febrianto (2015), the problem faced by PT Motasa Indonesia is that increased production will increase production costs and raw materials as well as delivery of finished materials to the market. This indicates that the costs required in the pepper production process are high. From the above explanation, it can be concluded that the threat of entry of newcomers is difficult, because the costs required in the processing process are high, as well as the distribution costs of raw materials obtained by the three main pepper producing centers in Indonesia and high finished goods.

\section{B. Substitute products}

Pepper contains chemicals including saponins, flavonoids, kanyo-fillene oxide, kariptone, essential oil, kavisin, resin, starch, piperine, piperiline, piperoleine, 
poperanine, piperonal, and pepper oil. The use of pepper in the food industry is as a meat preservative and food seasoning, and the addition of pepper to cooking produces a sharp, spicy taste and aroma (Yustina and Nurvia, 2012). The world market demand for pepper and its derivative products is high and seen from the characteristics possessed and the content of pepper above, substitutes or substitutes for pepper have not been found.

\section{Bargaining power of suppliers}

The bargaining power of suppliers can be a threat to a company if it has a dependency on one supplier from time to time. In addition, the bargaining power of suppliers affects the intensity of competition in an industry especially when there are a large number of suppliers, or when there are few good quality substitute raw materials, and/or when switching costs to other raw materials are very high. As well as the raw material for PT. Motasa Indonesia mainly comes from several pepper production centers in Indonesia, namely Bangka Belitung, East Borneo and Makassar. The number of suppliers that is more than one makes PT. Motasa Indonesia does not depend on just one supplier to meet the company's raw materials. In addition, the existence of the company Motasa Indonesia and Pepper Secret has been able to answer the needs of the community for an economical, high-quality, and safe-toconsume pepper derivative product. So it can be said that the position of the threat of supplier bargaining power in this business is weak because suppliers need the role of the pepper processing industry.

\section{Bargaining power of consumers}

According to Kuncoro (2006), the amount of bargaining power of buyers is based on three indicators, namely the large share of buyers, the number of substituted products, and the lack of product differentiation. Judging from the total production produced by each pepper production center in Indonesia, the share of buyers in this case the processing industry is very large because many regions produce pepper, and the lack of types of products obtained from suppliers results the strong bargaining power of buyers. However, besides that, the flavor of pepper that cannot be replaced by other products or the absence of substitutes makes the pepper industry's bargaining power weak because it cannot transfer its products to other goods to get the same use. So from the explanation of the three indicators of the bargaining power of consumers above, it can be concluded that the bargaining power of buyers or in this case the pepper processing industry is strong.

\section{E. Competition between the same industries}

The pepper processing industry into powder and other preparations such as oil and oleoresin are still very limited. and generally still processing raw materials into the same product, namely pepper powder, pepper oil, and oleoresin. PT Motasa Indonesia, which has modern technology and international standards in producing pepper both in the form of seeds and powder, indicates that there is competition between fellow pepper processing industries because this company also develops the side of product differentiation.

In addition to PT Motasa Indonesia, currently, there is also the Pepper Secret company, which is a pepper processing business that innovates to increase added value to pepper in the form of handcrafted and home care for bathing purposes made from the pepper. The products produced by Pepper Secret are mainly derived from pepper oil. The first product launched was Mandarin Peppercorn, which is a blend of mandarin orange and pepper. The product prices offered by Pepper Secret range from Rp. 15,000 to Rp. 300,000 and can be found in Belitung, Bali, and Jakarta. From the explanation above, it can be seen that there is competition in the pepper processing industry to produce various kinds of 
processed pepper products that are of high quality and according to market needs.

\section{External Attributes (Government and Opportunities)}

The government has a role as a facilitator or policy maker that stimulates business actors to continue to support pepper development. The government is unable to create competitive pepper and this can only be done by business actors including farmers to the downstream industry (Tambunan, 2004). Several policies that have been set by the government in the development of pepper in 2020, namely BUN500 plantation seed logistics, development of farmer/planter corporationbased areas, the transformation of traditional to modern spice plantations, comparative and competitive advantages (Downstreaming, Geographical Indications, Areas/Cluster), enhancement of Human Resources (BIMTEK, Vocational Education/Training, Youth Farmer Movement), access to financial financing, supply chain (Indonesian Spice Farmers Shop), and deregulation (Online Single Submission).

According to Andrianita (2020), Indonesia can take advantage of a trade agreement as an opportunity to increase the export market for Indonesian spices. Indonesia has entered into various cooperation agreements in the trade sector, such as the Free Trade Agreement (FTA), the Comprehensive Economic Partnership Agreement to the Preferential Trade Agreement (PTA). In addition, the increasing openness of the market due to globalization also demands diversification of pepper preparations, because innovation continues to develop. Indonesia as one of the producers and suppliers of pepper that already has black pepper (Lampung Black Pepper) and white pepper (Muntok White Pepper) brands in the international market can take advantage of this opportunity with its uniqueness while continuing to improve the existing quality.

\section{Indonesia's Participation in Global Value Chain}

Global value chains can strengthen economic connections between countries. According to the Ministry of Trade (2015), Indonesia's role in the global value chain is able to increase the comparative advantage of superior export commodities. The entry of a country in to the global value chain breaks up the production process in different countries until the company is able to specialize in a specific task and not produce the entire product. According to Lokadata (2020), the World Bank states that Indonesia's participation in global value chains is decreasing. This is due to several factors, such as the enormous dependence of Indonesian exports on raw materials, high transportation costs and the complexity of regulations.

Indonesia's participation in global value chains through forward and backward linkages decreased from 2000 to 2017. Forward linkages in global value chains decreased from $21.5 \%$ in 2000 to $12.9 \%$ in 2017, while backward linkages also decreased from $16,9 \%$ to $10,1 \%$ during the same period. The forward linkage shows a greater number than the backward linkage due to the fact that the largest economic activity is still in the upstream sector. According to the Asian Development Bank (2019), Indonesia's comparative advantage is concentrated in the primary and low-tech manufacturing sector industries. Such as manufacturing food, beverages, tobacco, rubber, and plastics as well as small equipment between 2000 and 2017. However, the mining and quarrying industry has a comparative advantage which fell from 3.4 in 2000 to 2.5 in 2017 and also refined fuels. and petroleum fell to 2.7 from 8.2 .

\section{Identification of Value Added in the Pepper Value Chain}

\section{a. Input}

According to Erliadi (2015) selective and efficient use of production factors will be able to provide maximum income. Low 
income will also affect the ability of farmers to manage plantations. Based on information obtained from pepper farmers in Tumbak Petar Village, Jebus District, West Bangka, Bangka Belitung Islands, local farmers are predominantly using the broad-leaf type of pepper seeds. This type of pepper is better known as Lampung wide leaf pepper. This type of seed has been used for a long time and has been hereditary. In an effort to develop the export commodity of pepper, from the input side, the government has carried out rehabilitation and intensification supported by the provision of superior quality seeds and other production facilities that can only be produced from garden sources of pepper seeds that have been determined according to standards.

The main focus of the government in the development of the pepper commodity in 2020 begins with building plantation seed logistics, namely building modern Nursery and Seed Source Gardens (KSB) in plantation development areas/clusters and distributing high productivity plantation seeds to be distributed free of charge to farmers/smallholder plantations. In 2019 to 2024, the target for the development of the pepper commodity includes expansion, rehabilitation and intensification, but does not include plant rejuvenation. Pepper expansion was carried out in 6 provinces and 16 districts, pepper rehabilitation was carried out in 6 provinces and 24 districts, and pepper intensification was carried out in 6 provinces and 17 districts. The total area for expansion and rehabilitation of pepper from 2019 to 2024 is 38,350 ha with $43,720,000$ seeds. The BUN500 pepper seedling process is supported by several processes such as supporting processes including certification and quality testing of plant seeds, monitoring of distribution, as well as partnership/cooperation between Provincial/Regency/City Offices, as well as producers or breeders. This is also supported by facilities and infrastructure such as tissue culture, as well as adequate greenhouses and irrigation.

\section{b. Production}

Pepper production activities in Jebus Village still use the traditional system. The pepper planting system is intercropped with several other plants such as avocado, duku, oil palm, and rubber. This is done to anticipate a drop in the price of pepper so that farmers can still get income from other crops. In the management of pepper plants, the workforce used in pepper farming generally comes from family members, depending on the type of activity carried out. According to Balitbangtan Bangka Belitung Islands (2013) pests and diseases are one of the factors causing the decline in pepper production. The main pests that attack pepper plants are stem borer, flower sucker, and fruit sucker. While the main diseases of pepper are jaundice, stem rot, and curly / dwarf disease. The main pest and disease control strategy for pepper can be carried out by applying recommended cultivation techniques, planting Arachis pintoi as a ground cover crop, and combined biological control with chemicals.

\section{c. Processing (Postharvest)}

The post-harvest process is an important indicator before pepper is bought and sold in the market. The post-harvest stages of pepper in Jebus Village include soaking, washing, removing the skin, and drying it. Each of these stages has a different time span, namely soaking for 1-2 weeks, washing for 1 day, removing the skin for 1 day, and drying the pepper for 2-3 days. The length of each stage depends on the weather conditions. The stages in the postharvest process will determine the quality of the pepper on the market in the market. The main problems that Indonesian pepper importers generally complain about are the high levels of dirt and microorganism contamination. At the exporter level, pepper produced by farmers is usually reprocessed to obtain black pepper with FAQ (Fair Average Quality) or ASTA (American Spice Trade Association) quality. 


\section{d. Market}

Post-harvest handling of pepper greatly affects the selling price of pepper. After the harvesting process is complete, the pepper will be stored and / or sold according to existing needs. Primarily, farmers in Jebus Village sell pepper to the nearest grocery store according to the prevailing price. The price obtained is influenced by several factors such as cleanliness, ripeness, and the degree of dryness of the pepper. Currently, the price received by farmers when selling to groceries is $\mathrm{Rp} 54,000$ per kilogram. The method of checking the level of dryness of the pepper is still traditional, namely by being bitten by $4-5$ peppers that have been dried in the sun and then if it breaks it means that the pepper is dry. After the process is complete, sales will be carried out individually without going through farmer groups. Sales are made in sacks and not packaged in good packaging. One of the efforts of the Province of Bangka Belitung Islands to restore the glory of pepper is by inaugurating the physical market for pepper together with the Joint Marketing Office (KPB). The pepper commodity will be traded in the form of a physical market on the Futures Exchange so that the pepper trading system is no longer from farmers through collectors but is directed directly to the physical market for pepper on the stock exchange.

\section{e. Credit}

In carrying out pepper farming activities, farmers need an investment cost of around 170 million rupiahs starting from year 0 of planting pepper. The amount of this cost is quite large, but there is no guarantee of income for pepper farmers due to the uncertainty of market demand and unpredictable price fluctuations that make farmers start to switch to planting other plantation crops. To overcome this problem, it is necessary to take a policy in the field of capital in the form of providing a soft credit system with easy and long term terms in accordance with the production life of the pepper plant.
Policies to increase the role of farmer groups or cooperatives are needed as an institutional provider of inputs, marketing of products, providers of credit (financing) and extension media. Some of the efforts taken to support the capital of the pepper plantations are the Integrated Partnership Project (PKT). PKT is an integrated partnership program involving large (core), small businesses (plasma) by involving banks as credit providers in a cooperative bond signed in a memorandum of understanding. The objectives of the PKT include increasing the feasibility of plasma, increasing mutually beneficial linkages and cooperation between nucleus and plasma, and helping banks to increase small business credit in a safer and more efficient manner.

In addition, there is also an implementation of the policy for the pepper commodity warehouse receipt system (SRG). According to Law No. 9 of 2011 concerning Amendments to Law No. 9 of 2006 concerning the Warehouse Receipt System, it is explained that the SRG aims to improve the welfare of the community which is an instrument formed with one of the objectives of empowering farmers, where the commodities it produces are able to provide economic value in the form of guarantees, which can be used to obtain credit and banks and institutions. non-bank finance, with low interest rates. Proof of ownership documents for goods stored in the warehouse issued by the Warehouse Manager. Farmers who submit their harvest to the warehouse company that has the right to issue warehouse receipts will receive evidence in the form of warehouse receipts. Thus, farmers do not need to be in a hurry to sell their produce during the harvest period, which is generally marked by falling commodity prices, as well as being able to obtain credit from banks to be used as working capital, such as buying seeds, fertilizers, and other necessities. 


\section{CONCLUSION AND RECCOMENDATION Conclusions}

The results from the calculation of the Revealed Comparative Advantage Index show that each country has an RCA index greater than (>) 1, so it can be said that the five largest exporting countries have a comparative advantage over pepper. Furthermore, according to the second research objective, the results of the analysis of the four attributes in Porter's Diamond Theory to compile the competitive advantage of Indonesian pepper show that Indonesia has an advantage in the condition of natural resource factors. Indonesia's tropical climate with high average rainfall throughout the year makes Indonesia an important area for spices. However, the large dominance of smallholder plantations has greatly influenced the fluctuations in the area of pepper cultivation in Indonesia. And, Indonesia's participation is decreasing in global value chains. This is due to several factors, such as the enormous dependence of Indonesian exports on raw materials, high transportation costs, and the complexity of regulations. The Indonesian pepper value chain analyzed by the Value Chain Approach shows that on the input side the main focus of the government in 2020 begins with building plantation seed logistics, namely building modern Nursery and Seed Source Gardens (KSB) in plantation development areas/clusters and distributing high-productivity plantation seeds free to farmers/smallholders. On the production side, pepper plant management activities are still mainly carried out traditionally and from generation to generation. Management of pests and diseases of pepper can be carried out by applying recommended cultivation techniques, planting Arachis pintoi as a ground cover crop, and combined biological control with chemistry. To maintain the stability of Indonesian pepper prices, it also requires strategic steps from stakeholders to maximize the value of the pepper commodity. One of the efforts of the
Province of Bangka Belitung Islands to restore the glory of pepper is by inaugurating the physical market for pepper together with the Joint Marketing Office. In the capital sector, several efforts were made to support the capital of the pepper plantations, namely the Integrated Partnership Project (PKT) and the Warehouse Receipt System (SRG).

\section{Recommendations}

From the results of this study, the researchers suggest that the comparative advantages possessed by Indonesian pepper can be improved by implementing Good Agricultural Practices which are expected to increase the ability to handle food safety issues in each stage of pepper management to reduce the risk of rejection from the international market due to the high content of impurities and microorganisms in pepper that cause pepper. The competitive advantage of Indonesian pepper on the condition of natural resource factors needs to be through the use of high-yielding resistant varieties; in addition to that, experimentation on planting patterns such as Vietnam, namely intercropping with rubber can be carried out to reduce the productivity of pepper plants to be maximized. Also to increase the added value in Indonesia's value chain, it is deemed necessary to have synergy between the central government and the government in developing digital market development as a forum to expand and facilitate consumers in obtaining pepper from various pepper production centers.

\section{Acknowledgement: None}

\section{Conflict of Interest: None}

\section{Source of Funding: None}

\section{REFERENCES}

1. Andrianita, Olvy. Kembangkan Pasar Rempah Indonesia Bisa Manfaatkan Perjanjian Dagang. Retrieved August, 12 2020; Available from: https://nasional. kontan.co.id/news/kembangkan-pasar- 
rempah-indonesia-bisa-manfaatkanperjanjian-dagang.

2. Anindita, Ratya, Michael R. Bisnis dan Perdagangan Internasional. Yogyakarta, Indonesia: Andi; 2008.

3. Asian Development Bank. 2019. The Evolution of Indonesia's Participation in Global Value Chains. Philippines, Philippines: Asian Development Bank; 2019.

4. Balai Pengkajian Teknologi Pertanian Kepulauan Bangka Belitung. Hama dan Penyakit Tanaman Lada beserta Strategi Pengendaliannya. Retrieved August 28, 2020; Available from: http://babel.litbang.pertanian.go.id/index.p $\mathrm{hp} / \mathrm{sdm}$-2/15-infoteknologi/204-hamadan-penyakit-tanaman-lada-besertastrategi-pengendaliannya

5. Cho, Dong Sung, Hwy-Chang Moon. From Adam Smith to Michael Porter. Singapore, Singapore: World Scientific Publishing. Co Pte Ltd, 2000.

6. Djulin, Adimesra, A. Husni. Struktur dan integrasi pasar ekspor lada hitam dan lada putih di daerah produksi utama. Jurnal Sosial Ekonomi Pertanian. 2002; 5(1): 111

7. Erliadi. Faktor-faktor yang mempengaruhi minat petani menggunakan benih varietas unggul pada usahatani padi sawah (Oryza sativa, L) di kecamatan Manyak Payed kabupaten Aceh Tamiang. AGRISAMUDRA. 2015; 2(1): 91-100.

8 Febrianto, Galih. Strategic fit supply chain dalam industri pengolahan merica bubuk studi kasus PT. Motasa Indonesia [thesis]. 2015. Surabaya, Indonesia: Universitas Airlangga.

9. International Pepper Community. Pepper Statistical Yearbook 2018. 2019; Jakarta, Indonesia: International Pepper Community.

10. Kaplinsky, Raphael and Mike Morris. A Handbook For Value Chain Research. 2001;Available from http:/www/fao.org./fileadmin/user_upload /fisheries/docs/Value_Chain_Handbook.p df

11. Kholid, Mukhammad Mawardi. Persaingan industri ritel di Indonesia dengan Model 5 kekuatan pesaing $\mathrm{M}$.
Porter. Jurnal Ekonomi dan Bisnis Islam, 2010; 4(3):1-12.

12. Kuncoro, Mudrajad. Strategi: Bagaimana Meraih Keunggulan Kompetitif?. Jakarta, Indonesia:Penerbit Erlangga; 2006.

13. Kim, W. C., R. Mauborgne. 2009. How strategy shapes structure. Harvard Business Review (September): 72-80. [internet] Retrieved 2020 October 20. 2020; https://hbr.org/2009/09/howstrategy-shapes-structure.

14. Ministry of Trade. (2015). Analisis Potensi dan Manfaat Rantai Nilai Kawasan Regional Comprehensive Economic Partnership Bagi Indonesia. Retrieved 2020 March 25. Available from:

http://bppp.kemendag.go.id/media_conten t/2017/08/Analisis_Potensi_Ranta

i_Nilai_Kawasan_RCEP_Bagi_Indonesia. pdf

15. Rivaie, A. Arivin, Effendi Pasandaran. Memperkuat Daya Saing Produk Pertanian. Badan Litbang Pertanian. Jakarta, Indonesia: Kementerian Pertanian; 2014

16. Sinungan, Muchdarsyah. Produktivitas Apa dan Bagaimana. Jakarta, Indonesia: Bumi Aksara; 1992.

17. Soetriono. Daya Saing Pertanian dalam Tinjauan Analisis. Malang, Indonesia: Bayumedia Publishing: 2006.

18. Suandy, Erly. Evolusi Teori Daya Saing terjemahan edisi pertama. Jakarta, Indonesia: PT. Salemba Empat, 2003.

19. Syam, Amiruddin. Efisiensi Produksi Komoditas Lada di Provinsi Bangka Belitung. Sulawesi Tenggara, Indonesia: BPTP Sulawesi Tenggara, 2004.

20. Tambunan, Tulus. Globalisasi dan Perdagangan Internasional. Jakarta, Indonesia: Ghalia Indonesia, 2004.

21. Tatakomara Edwin. Analisis faktor-faktor yang mempengaruhi ekspor komoditi teh indonesia, serta daya saing komoditi teh di pasar internasional [Skripsi]. 2004. Bogor, Indonesia: Institut Pertanian Bogor.

22. Tiurlina, Minas, Siti Amanah, Prabowo Tjitropranoto. Persepsi Petani Lada terhadap Diseminasi Teknologi Usahatani Lada di Bangka Belitung. Jurnal Penyuluhan, 2016; 12(1) : 61-73 
23. Trade Map. Billateral Trade Between Indonesia and World Product 090411 and 090412. Switzerand, Europe: International Trade Center; 2019.

24. Yazmi, Adi Suyatno, Imelda. Analisis finansial usahatani lada putih (piper nigrum linn) di desa ratu sepudak kecamatan galing kabupaten sambas provinsi Kalimantan Barat. Journal Social Economic of Agriculture, 2017; 6(2): 4256.

25. Yulihendri. Semester II 2018 Ada 10.077 Petani Lada di Belitung Dengan Jumlah Produksi Rata-rata 1,1 Ton. [internet].
Retrieved on 2020 July 28. 2020; Available from: https://bangka.tribunnews.com/2018/08/1 2/semester-ii- 2018-ada-10077-petanilada-di-belitung-dengan-jumlah-produksirata-rata-11-ton.

How to cite this article: Amorita C, Daryanto A, Sahara. Competitiveness analysis of Indonesian pepper in international market. International Journal of Research and Review. 2021; 8(5): 38-52. DOI: https://doi.org/10.52403/ijrr.20210507 